\title{
STING contributes to anti-glioma immunity via triggering type-I IFN signals in the tumor microenvironment
}

Takayuki Ohkuri ${ }^{1,6}$, Arundhati Ghosh ${ }^{4,8}$, Akemi Kosaka $^{1,6}$, Jianzhong Zhu ${ }^{4,8}$, Maki Ikeura ${ }^{6}$, Michael David ${ }^{9}$, Simon C Watkins ${ }^{5}$, Saumendra N Sarkar ${ }^{3,4,8}$, Hideho Okada ${ }^{1,2,3,6,7^{*}}$

From Society for Immunotherapy of Cancer 29th Annual Meeting

National Harbor, MD, USA. 6-9 November 2014

While type-I interferons (IFNs) play critical roles in antiviral and antitumor activity, it remains to be elucidated how type-I IFNs are produced in sterile conditions of the tumor microenvironment and directly impacts tumor-infiltrating immune cells. We report that both human and de novo mouse gliomas show increased expression of type-I IFN messages, and in mice, CD11b ${ }^{+}$ brain-infiltrating leukocytes (BILs) are the main source

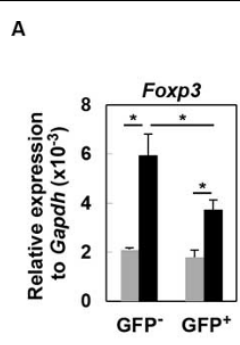

。

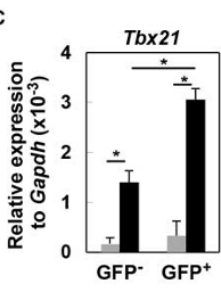

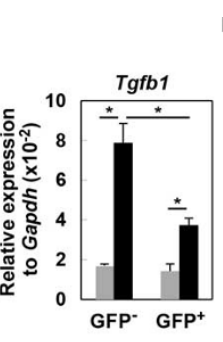

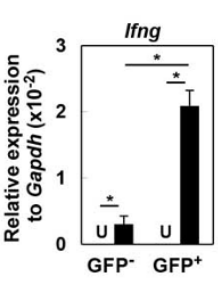

B

Without $\mathrm{CD} 3$ beads With $\mathrm{CD} 3$ beads CD8 alone CD8+ GFP+CD4 CD8+ GFP-CD4
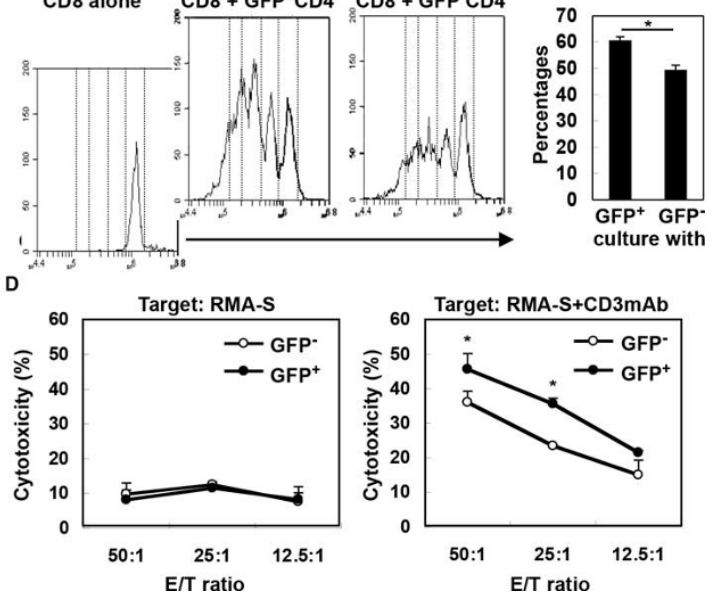

Figure 1 Type-I IFNs directly impact on T-cell functions in glioma-developing mice. (A) $C D 4^{+}$cells from draining LN derived from gliomadeveloping tdTomato mice were sorted into GFP- or GFP' cells and incubated with (black bars) or without (grey bars) anti-CD3mAb. After $4 \mathrm{~h}$, total RNA was extracted for evaluation of Foxp3 and Tgfb 1 mRNA levels by qRT-PCR. (B) CFSE-labeled WT CD8 ${ }^{+}$T-cells were co-cultured with $\mathrm{GFP}^{-}$or GFP ${ }^{+} \mathrm{CD}^{+}$T-cells in the presence of $\mathrm{CD} 3$ beads. After $60 \mathrm{~h}$, division of CFSE-labeled CD8 ${ }^{+}$T-cells gated by reactivity to PE-Cy7condjugated anti-CD8mAb was evaluated by CFSE intensity. As a negative control, CFSE-labeled WT CD8 ${ }^{+}$T-cells were cultured without any stimulation (left panel). Histograms are representative of two independent experiments. The bar graph shows the percentage of CD $8^{+}$cells that have divided at least twice in each of two stimulation conditions ( $N=4 /$ group; $\left.{ }^{*} p<0.05\right)$. (C) GFP ${ }^{-}$or $\mathrm{GFP}^{+} \mathrm{CD} 8^{+}$T-cells were incubated with (black bar) or without (grey bar) anti-CD3mAb. After $4 \mathrm{~h}$, total RNA was extracted for evaluation of Tbx21 and Ifng mRNA expression levels by qRT-PCR (U: undetected). (D) Cytotoxic activity of GFP- and GFP+ $\mathrm{CD}^{+}$T-cells was evaluated by ${ }^{51} \mathrm{Cr}$-release assay. RMA-S cells untreated (left panel) or pretreated (right panel) with anti-CD3mAb $(10 \mathrm{~g} / \mathrm{mL})$ were used as target cells. ${ }^{*} p<0.05$ compared at the same $E / T$ ratio.

'Department of Neurological Surgery, University of Pittsburgh School of Medicine, Pittsburgh, PA 
of type-I IFNs that is induced partially in a STING (stimulator of IFN genes)-dependent manner. Consequently, glioma-bearing Sting ${ }^{G t / G t}$ mice showed shorter survival, and lower expression levels of Ifns compared with wild-type mice. Furthermore, BILs of Sting ${ }^{G t / G t}$ mice show increased $\mathrm{CD} 11 \mathrm{~b}^{+} \mathrm{Gr}-1^{+}$immature myeloid suppressor and $\mathrm{CD} 25^{+}$Foxp $^{+}$regulatory $\mathrm{T}$ (Treg) cells, while decreased IFN- $\gamma$-producing $\mathrm{CD}^{+} \mathrm{T}$ cells. To determine the effects of type-I IFN expression in the glioma microenvironment, we utilized a novel reporter mouse model, in which the type-I IFN signaling induces the $M x 1$ (IFN-induced GTP-binding protein) promoterdriven Cre recombinase, which turns the expression of loxp-flanked tdTomato off, and turns green fluorescence protein (GFP) expression on, thereby enabling us to monitor the induction and effects of IFN signaling in the glioma microenvironment. $\mathrm{CD}^{+} \mathrm{T}$ cells that received direct type-I IFN signals (i.e., $\mathrm{GFP}^{+}$cells) demonstrate lesser degrees of regulatory activity based on lower Foxp3 and $T g f b 1$ expression levels (Figure 1) as well as lesser suppression of $\mathrm{CD} 8^{+} \mathrm{T}$ cell proliferation (Figure B). IFN-sensed $\mathrm{CD} 8^{+} \mathrm{T}$ cells exhibit enhanced levels of Th1 markers, Tbx21 and Igfng (Figure C), as well as cytotoxic T-cell activity based on reverse antibody-dependent T-cell-mediated cytotoxicity assay (Figure D). Finally, intratumoral administration of a STING agonist (cyclic diguanylate monophosphate; c-diGMP) improves the survival of glioma-bearing mice associated with enhanced type-I IFN signaling, $\mathrm{Cxcl10}$ and $\mathrm{Ccl} 5$ and $\mathrm{T}$ cell migration into the brain. In a combination with subcutaneous OVA peptide-vaccination, c-di-GMP increased OVA-specific cytotoxicity of BILs and prolonged the survival. These data demonstrate significant contributions of STING to antitumor immunity via enhancement of the type-I IFN signaling in the tumor microenvironment, and imply a potential use of STING agonists for development of effective immunotherapy, such as the combination with antigen-specific vaccinations.

\footnotetext{
Authors' details

${ }^{1}$ Department of Neurological Surgery, University of Pittsburgh School of Medicine, Pittsburgh, PA. ²Department of Surgery, University of Pittsburgh School of Medicine, Pittsburgh, PA. ${ }^{3}$ Department of Immunology, University of Pittsburgh School of Medicine, Pittsburgh, PA. ${ }^{4}$ Department of Microbiology and Molecular Genetics, University of Pittsburgh School of Medicine, Pittsburgh, PA. ${ }^{5}$ Department of Cell Biology and Physiology, University of Pittsburgh School of Medicine, Pittsburgh, PA. ${ }^{6}$ Department of Brain Tumor, University of Pittsburgh School of Medicine, Pittsburgh, PA. ${ }^{7}$ Cancer Immunology, University of Pittsburgh Cancer Institute, Pittsburgh, PA. ${ }^{8}$ Cancer Virology Programs, University of Pittsburgh Cancer Institute, Pittsburgh, PA. ${ }^{9}$ Division of Biology, UCSD, La Jolla, CA.
}

Published: 6 November 2014
doi:10.1186/2051-1426-2-S3-P228

Cite this article as: Ohkuri et al: STING contributes to anti-glioma immunity via triggering type-I IFN signals in the tumor microenvironment. Journal for ImmunoTherapy of Cancer 2014 2(Suppl 3): P228.
Submit your next manuscript to BioMed Central and take full advantage of:

- Convenient online submission

- Thorough peer review

- No space constraints or color figure charges

- Immediate publication on acceptance

- Inclusion in PubMed, CAS, Scopus and Google Scholar

- Research which is freely available for redistribution

Submit your manuscript at www.biomedcentral.com/submit 